\title{
PROBLEMS IN ALBERTA'S TOWN PLANNING LEGISLATION
}

\author{
W. A. StBuenson*
}

There has until recently been a very strong tendency among lawyers as well as laymen in Alberta to shun any formal research in the field of town planning law and instead simply to "ask the boy at the desk" what the zoning of an area is. However, the recent report by the Honourable Mr. Justice M. M. Porter on Edmonton's civic affairs ${ }^{2}$ has cast considerable doubt upon the accuracy of this over-the-counter advice and has necessitated a re-appraisal of "the maze of statutes, by-laws, regulations and rulings" that make up our town planning legislation. The purpose of this paper is to discuss Alberta's town planning legislation, especially as it is applied or misapplied in the City of Edmonton.

The principal statute which we must consider is The Town and Rural Planning Act, R.S.A. 1955, c. 337, as amended. It is not unfair to legislative counsel to say that most of the recent town planning legislation has been prepared and presented by the professional town planners employed by the province and by the cities. One unfortunate result of this tendency has been a spate of piecemeal amendments to the Act; in 1958 alone, there were twentythree specific amendments.

Our town planning legislation may be conveniently discussed under four headings:

(1) Replotting,

(2) The General Plan,

(3) Zoning,

(4) Interim Development.

\section{(1) Replotting.}

Most Canadian jurisdictions do not regard the plotting power as a planning power. However, it is so treated and so used in Alberta. It is also used here, and this is the more serious problem, as a means of expropriation.

The Act simply states that a municipal Council may prepare a scheme for cancelling an existing subdivision, making a new one and redistributing the lands. ${ }^{3}$ Any replotting scheme must have the approval of landowners owning at least sixty percent of the assessed value of lands involved in the scheme."

"W. A. Stavinson, B.A., LL.B., Member of the firm of Morrow, Morrow, Reynolds and Stevenson.

${ }^{1}$ In the Matter of the City Act, being c. 42, R.S.A., 1955 as amended and In the Matter of an Inquiry into certain matters as outlined in a Resolution received from the Council of the City of Edmonton under 3.728 of the said Act.

The Report of the Honourable Mr. Justice Poster, hereinafter referred to as the Porter Inguiry.

2Porter Inquiry, p. 94.

3The Town and Rural Planning Act, s. 34.

IIbid., s. 36. 
In other provinces whose Town Planning Acts contain replot sections, ${ }^{5}$ there are at least three sections, absent from our Act, which restrict the replot power. These provide that

1. Any replot scheme requires the approval of the responsible Minister.

2. Lands owned by the Crown may not form part of a replot scheme.

3. A replot scheme must be "necessary to facilitate development"."

These three safety provisions are absent from our Act with the result that the replot power may be abused. If the Town Planner desires to replan an area of the City, for example, to create a new road, and a person whose property is necessary to the scheme resists, the replot powers may be used to coerce that person into trading his property for other, perhaps less valuable property. That abuse of the replot power is not just a possibility is illustrated by the Porter report, where several actual cases of abuse are discussed. What Mr. Justice Porter described as "a flagrant example of the misuse of the replot powers"' is the case of Mrs. Bertha Boyko. The following are the facts as found by the Commission:

"Mrs. Bertha Boyko owned a parcel containing several lots contiguous to a school site which the sehool board desired to expand. They found themselves unable to negotiate a voluntary purchase from her at a price that they thoughe was appropriate. They therefore induced the City to undertake replot proceedings as a result of which the school board wound up with two lots out of Mrs, Bopko's property and she was given two others whose location gave them no such value as those she had been deprived of because there was no contiguous oceupant in like need of land to the need of the board. There was doubt that the board could have expropriated because the necessity for the lands as distinct from the convenience of having them, was not cleat."

After discussing this and other actual cases involving the misuse of the replot power, Mr. Justice Porter concludes by saying that the replot power, when misused,

"is in effect a cruel method of expropriation which denies appropriate compensation to its victim."10

The "cruelty" is further indicated by the difference in the right of appeal. Whereas a person aggrieved by an expropriation order under Section 298 of The City Act ${ }^{11}$ may appeal to the Board of Public Utility Commissioners, "to determine whether the plan of development concerned is in the public interest", a person aggrieved by a replot order may appeal to the same Board only on the question of compensation."

It is not the opinion of the writer that replotting is to be condemned in toto. It has a legitimate sphere of operation, for example, where there is one hundred percent agreement. But where the problem is to secure the operation of a proper

SSaskatchewan and British Columbia.

OThus a perzon aggrieved by a replot oxder could sue in the ordinary courts for a declaratory judgment that a by.law was invalid as not necessary to facilitate development. It may be that a similar action is now available under our Act as a result of the amendment of the Act in 1958 by adding s. 29.

TPoster Inquiry, pp. 68.9, (Buena Vista property), pp. 62.5 (Boulevard Heights) and pp. 67.8 (Ostap Lech.).

sPorter Inquiry, p. 66.

DPorter Inquiry, p. 66.

10Porter Inquiry, p. 69.

11R.S.A. 1955, c. 42.

12The Town and Rural Planning Act, ss. 49.56. 
general plan, the replot scheme is unsatisfactory and unnecessary as the Legislature has already provided expropriation apparatus in Sections 76 and 77 of The Town and Rural Planning Act and Section 298 of The City Act.

\section{(2) The General Plan.}

All planning statutes which the writer has examined ${ }^{13}$ are centered around the concept of a "General Plan". The concept was enunciated in our first Town Planning Act of 1913," where it was called a "scheme"-"with the general object of making suitable provision for traffic, proper sanitary conditions, amenity and convenience". The General Plan, under the present Act, is a statement "setting out the manner in which the Council considers the development of the municipality should be carried out within a defined period of time, having regard to considerations of orderliness, economy and convenience, and setting out the means and steps necessary to ensure or to effect that manner of development". ${ }^{3}$ It may include proposals relating to use or development of land, allocation for specific purposes, reservation of public lands, the planning of development, and the nature and contents of a zoning by-law to ensure that private development accords therewith. ${ }^{16}$ Thus the General Plan is essentially a scheme, but not a map, for the establishment of the goals, objectives and policy of planning, together with the statement of the analysis of facts and trends relevant thereto and the method of bringing these together. However, it is important to note that the statute envisages a General Plan of a more or less fixed character, one upon which a City can be built and legislation erected. It may of necessity be changed from time to time but to characterize it as an "evolving concept" may satisfy the planner but not the statute. The importance of the General Plan is that it is the ultimate aim of our present statutes, the existing regulations are only stop-gap measures before the creation of a General Plan.

Once a General Plan is adopted the immediate effect is to prevent the Council from commencing any undertaking within the purview of the Plan but inconsistent with it. ${ }^{13}$ In addition, Council is empowered to adopt schemes to put the proposals in the Plan into effect ${ }^{13}$ and they are given the power under The City Act to expropriate. ${ }^{10}$ It is important to note that the General Plan, per se, affects only the activities of the municipality. The individual person will be controlled by zoning by-laws.

Although the concept of the General Plan has been embodied in our town planning legislation since 1913, this writer knows of no Council in Alberta which has in fact prepared a general plan. The attitude in Alberta may be compared to that of an Oxford skeptic who has termed the General Plan an "unintelligible formulation of an indefinite project for an uncertain purpose".

\footnotetext{
${ }^{13}$ Alberta, Saskatchewan, British Columbia, Manitoba, Ontario, Imperial.

14An Act relating to Town Planning, 1913, c. 18.

$1 \mathrm{~s}_{\mathrm{g} .} 63$ (1).

16. 65 .

$17_{3}, 67(2)$.

$18_{8}, 63(2)$.

10Supra.

20Thomas Sharpe, cired in Cases and Materials on the Lay and Administration of Community Planning, ed. J. B. Milner. 1958, vol. 2, p. 301.
} 
What is more, the Alberta Minister of Town Planning has never made use of his power to proceed in the case of default by a Council to carry out its duty and make a plan for that area. ${ }^{21}$ In other words, there is a deliberate refusal on all sides to put into practice the concept of the General Plan. The reason usually given for this attitude is that the absence of a General Plan leaves the situation more flexible. However, my submission is that the price we will pay for flexibility is an extremely high one. One of the most serious effects of planning is its effect on land values, and that effect is, of course, proportionate to the degree of flexibility allowed. The foregoing does not mean that a general plan cannot be changed. There is a procedure set out in our Act for that very purpose." Indeed, English town planning legislation requires every planning unit to revise its plan every five years. But the difference between the periodic revision fo a general plan and the "flexibility" of interim development is that the procedure for revising the plan is designed to minimize fluctuations in land values by leaving the changes open to careful scrutiny by the Council and the public.

\section{(3) Zoning.}

We are still in the land of theory because, contrary to popular opinion, there is no zoning in Edmonton or in Calgary. The City of Edmonton's zoning by-law was suspended in 1950 by Ministerial order authorizing the preparation of a general plan and the exercise of interim development control.

The Act gives Council the power to pass a zoning by-law dividing the municipality into districts and prescribing the purposes for which buildings and land may be used." The by-law shall be based upon a survey of the existing uses and an analysis of the future needs for development of the municipality. ${ }^{24}$

The by-law is required to state the uses permitted within the district and may contain regulatory provisions. ${ }^{23}$ It is necessary to provide an Appeal Board which can reverse or modify a discretionary ruling and relieve against hardship. ${ }^{28}$

When a zoning by-law is passed, a building may exist which does not conform with the new zoning. Such a non-conforming use may be continued, but if the use is discontinued or changed, any future use shall conform to the provisions of the by-law." A non-conforming building shall not be enlarged, added to, rebuilt or structurally altered except as required by statute or by-law as may be necessary to make it a conforming building, or as may be deemed necessary by Council or its agents for the routine maintenance of the building. ${ }^{28}$

It would appear that a Council framing a zoning by-law must bear in mind several limitations to their power imposed by the courts. First, Egbert, J. in-

21The Town and Rural Planning Act, 3. 95.

22s. 84.

$23_{8}, 80$ (1).

24. 80 (1a).

$2 x_{3 .} 80$ (3) (4).

$28_{3}, 81$.

$27_{3} .82(3)$.

$28_{3 .} 82$ (1). 
dicated in City of Calgary v. Reid ${ }^{29}$ that the Council is not permitted to delegate its power to pass a zoning by-law. ${ }^{30}$ Also a by-law passed by a Council must be framed so as to avoid attack on grounds of uncertainty, ${ }^{\text {at }}$ unreasonableness $^{32}$ and discrimination. ${ }^{33}$ The last is particularly important because it would appear that most spot zoning, that is, a zoning by-law which refers to a single individual, or which is passed for the benefit of a single individual falls within the prohibition of discriminatory legislation.

In the writer's submission, the primary problems of our zoning legislation are as follows:

1. The provision of an adequate system of appeals from the decision of a local Council.

2. A delineation of the proper content of zoning by-laws and in particular a reconsideration of the power given to Council to pass a by-law requiring almost complete conformity. The description in our Act of the possible contents of a zoning by-law is probably broader than any other Act in Canada, especially where our by-laws can provide for "the design, character and appearance of buildings and of fences and structures other than buildings." ${ }^{34}$

3. Compensation. No Canadian statute provides for compensation as a result of changes in zoning. This lack of compensatory provisions suggests an absence of realization by our legislators that zoning by-laws which, for example, change an area's zoning from industrial or twofamily dwelling to parkland or agricultural, will cause severe economic depreciation of that area.

(4) Interim Development.

This is the most important practical area of town planning law at present because both Edmonton and Calgary are now under interim development control and Edmonton has been in this position since $1950 .^{85}$ It is interesting to note that interim development was first introduced in Alberta, and that the provisions in the Act were the result of representations by the City of Edmonon. Section 68 (2) says:

"Control shall be exereised over the development within the municipality by the Council on the basis of the merits of each individual application for permission to develop, having regard to the proposed development conforming with the general plan being prepared."

What the Act envisages is control over "development" during the period of preparation of a general plan. As Professor Milner points out, looking at the Edmonton experiment, "The real danger of interim control is that it soon becomes control and loses its interim quality.

20(1958.59) 27 W.W.R. 193 (T.J. and App. Div.).

30See also Simmon v. Gastonguay [1931] 2 M.P.R. 470; Re Halladay and Ottarva (1907)

15 O.L.R. 65; and cases cited in Milner, op. cit., vol. 1, pp. 183.201.

31 Re Goldstein and City of Windsor (1928) 35 O.W.N. 9.

s2Kruse v. Johnson [1898] 2 Q.B. 91.

${ }^{3 a}$ Cases cited in Milner, op. cit., vol. 1, pp. 169.183. See also Re Loiselle, 7 W.L.R. 42;

Re Wier 7 W.L.R.; Bondi v. Scarborough, (1957) il D.L.R. 358.

34The Town and Rural Planning Act, s. 80 (6) (a) (v).

${ }^{85}$ In this section, we will consider particularly interim development as applied in Edmonton.

soMilner, op. cit., vol. 2, p. 374. 
The exercise of interim control can only be authorized by the Minister. Before the Minister can authorize interim development, Council shall show to him a statement of the arrangements that have been made for the preparation of a general plan, after which if the Minister is satisfied that these arrangements are satisfactory, he may give the necessary authority. ${ }^{37}$

The differences between zoning and interim development may well be noted. Zoning by-laws may be passed by City Council without any authority given by the Minister; interim development control is exercisable only after a Ministerial order. Zoning by-laws may be passed whether a general plan is in preparation or not; interim development control is possible only in the interim between the commencement of preparation and the completion of a general plan.

In considering this legislation, it is necessary first to note that there is no definition of development in the Act. The dictionary definition is a movement to a higher, from a lower, state. ${ }^{38}$ The Appellate Division in the Reid case ${ }^{30}$ made it clear that there must be some physical change, and changes in use or density appear not to be included.

In contrast with the Act, both the order and the Edmonton by-law ${ }^{40}$ set out very wide definitions of development. The by-law defines development as follows: :1 $^{2}$

"The by-law then goes on to provide that "development" includes, inter alia, changes in density of population, any alterations in a building resulting in its greater use, the display of advertisements, the deposit of refuse, the removal of topsoil, and the more frequent or intense use of land for certain purposes." "Development" is then said not to include certain matters, especially nonconforming uses. This definition appears to have been taken from the definition section in the 1948 Imperial Act.

The extreme broadness of the wording of the definition of development in the by-law suggests that there has not been much thought given to the effect of giving sweeping control over all development to Council. Treated as it is presently by the City of Edmonton, this by-law, like the English Town Planning Act, purports to exproptiate the development value of all land in the City of Edmonton, but without the compensation machinery present in the 1947 English legislation. This by-law is a drastic interference with property rights without any clear indication of legislative intent and in the face of Section $2 \mathrm{a}$ of the Act, ${ }^{42}$ as well as the common law. My submission is that these wide definition sections in the by-law will be strictly construed for two reasons:

1. These sections interfere with property rights, and

\footnotetext{
37.35. 68-70.

38Webster's New International Dictionary 2nd ed., p. 713.

aUSupra., footnote 31.

10By-law No. 1988, Interim Development By.law No. 2, "A By.law to continue Interim Developmene Control in the City of Edmonton pursuant to the provisions of The City of Edmonton Interim Development Order No. 2, dated June 8th, 1959", passed September 1 st, 1959.

41By-law No. 1988, 8. (5).

"the carrying out of building, engineering or other operationa in, on, over or under land, or the making of any change in the use or intensity of use of any land or building."
} 
2. Section 2a of the Town Planning Act seems clearly to restrict the powers granted in that Act including interim development control. ${ }^{42}$

The second, and more important, aspect of the statute is that Council must exercise control of interim development and cannot delegate this function. It was upon the basis of this section that Egbert, J. in City of Calgary v. Reid ${ }^{20}$ held that the Calgary interim development by-law which attempted to delegate the power to exercise interim development control was ultra vires. On appeal, he was affirmed on narrower grounds. The old City of Edmonton by-law, number 1335, was similar to the Calgary by-law and the writer is satisfied that the Edmonton by-law was also within the scope of the Reid judgment, despite the existence of an appeal to City Council.

In 1959, the Act was amended to provide for two activities of Council concerning interim development control which could be delegated. S. 71 (a) (2) reads:

"A council may, by by-law, delegate to the Interim Development Board ot the Interim Development Officer authority to consider and decide on its behalf any application concerned with matters within the scope of those parts of the general plan or policies concerning development that have been adopted by resolution of the council."

In my submission, this amendment makes no change in the present position that all applications for development, whatever that term means, must be made to Council. It is obvious that none of the general plan has been adopted and that at this moment there are no policies adopted by resolution of Council, if indeed such policies could be formulated which would not be bad for uncertainty.

Despite these objections, the new city by-law, apparently pursuant to the sections in the Act cited above, does delegate interim development control to subordinate officials. S. 7 (2) of the by-law says that the development officer is authorized to consider and decide, on behalf of Council, any application concerned with matters within the scope of those parts of the general plan that have been adopted by resolution of Council and in these cases he may grant, or grant on condition, or refuse the application. There is a right of appeal to Council, and thence to the Provincial Planning Advisory Board.

If conditions are imposed by the development officer or by City Council, they may be embodied in an agreement which shall be deemed to be a covenant running with the land and the City may encumber the title accordingly. ${ }^{3}$ A building permit is valid for six months, but may be extended to a year, ${ }^{41}$ a pro. vision which renders the granting of a permit of small comfort to a builder constructing any large building. The by-law also provides that if a permit is modified when granted, the person seeking the permit will receive compensation determined by compulsory arbitration. ${ }^{45}$ Finally, the by-law creates an architectural panel to consider and advise on any or all applications for permission to display any sign and to advise on architectural design and control. ${ }^{46}$ In its

62, $2 \mathrm{a}$ states "The purpose of this Act is to provide means whereby municipalities, either simply or jointly, may plan for orderly and cconomical development without infringing on the rights of land owners except to the extent that is necessary, for the greater public incerest, to obtain orderly development and use of land in the Province." See supra., footnote 6.

49By-law No. 1988, s. 10.

Hy-law No. 1988, s. 11.

45y-law No. 1988, s. 14.

${ }^{46 B}$ By.law No. 1988, s. 15. 
terms and having regard to the statute, the board can only be advisory and then only to the City or the officer. Nevertheless, the present practice is to make the decision absolute.

One vast improvement in the by-law is that it finally divorces the old zoning by-law from the interim development by-law. For the past nine years the old interim development by-law incorporated a 1933 zoning by-law, this notwithstanding the fact that both the Act and Ministerial order suspended the by-law. Despite this change, the writer understands that city officials are still seriously advising citizens as to the "zoning" of a particular area.

\section{(5) Conclusion.}

In any system, there must be the following decisions made and there has been a singular lack of discussion of these difficult problems.

1. How much control is necessary? Are we to have only a broad framework or are we to be minutely regulated? How much conformity in use of land is necessary or desirable?

2. In whom should the power be vested? Our elected representatives? A body of professional town planners?

3. What safeguards are we to have? Judicial appeal? Appeal to Council? Ministerial approval? Appeal to professional planners (which we have now)?

4. What are we going to do about the problem of compensation? Any scheme is going to hurt somebody. It is also likely to create a substantial increment in value for someone. That is so on the passing of a zoning by-law, the introduction of a general plan or interim development. Should the profit or loss fall where it may? That is the general idea in this country at the present time, the primary concession being the permission granted to continue a nonconforming use. But if we think of examples of changes in zoning, for example, from agricultural to industrial, from industrial to service station, from business to park, we can see the vast problems and, the writer suggests, the harsh inequities. Once the by-law is in force, or a general plan is approved, the people buy with notice and perhaps must be fixed with the chance of loss or gain. At one time our general plans provided for compensation. They do not now. The problem is even more acute under interim development, because not only is there the difficulty created by instability at the inception but also the fact that there is no blueprint for the future and we run a tremendous risk in acquisition of land. People have been and will continue to be made or broken by these piecemeal decisions. Our planners may say that England has a similar system. But England has realized exactly what it was doing. It expropriated the deveJopment value of land. It set up a 300,000,000 pound fund to be distributed among all landowners who claimed any compensation. It also imposed a 100 percent. increment tax and thus levelled the landowners, but at least it was fair. There have been subsequent modifications, delaying the time for payment, but the important thing is that the problem was dealt with. In my submission, despite Section 2a of the Alberta Town and Rural Planning Act, our legislators have not even appreciated the problem. 